\title{
Agronomic Performance of Cultivars of Vignasubterranea (L.) from Côte d'Ivoire and Burkina Faso Cultivated under different Environments
}

\section{Ahou Suzane Komenan-Ani, Kouamé Kévin Koffi*, Kouakou Laurent Kouakou, Kouadio Ignace Kouassi and Bi Irié Arsène Zoro}

\author{
University Nangui Abrogoua. Department of Natural Sciences, Laboratory of Genetics, 02 BP \\ 801 Abidjan 02, Côte d'Ivoire.
}

Article No.: 042916081

DOI: 10.15580/GJAS.2016.6.042916081

Submitted: $29 / 04 / 2016$

Accepted: 05/05/2016

Published: $24 / 06 / 2016$

${ }^{*}$ Corresponding Author

Kouamé Kévin Koffi

E-mail: koffikevin@yahoo.fr

Phone: (225) 09872698

Keywords:

Bambara groundnut,

Vignasubterranea, cultivars,

Agronomic performance, study

sites $x$ seeds origin
Bambara groundnut [Vignasubterranea (L.) Verdc.] is an important grain-legume. The plant is grown in diverse agro-ecological conditions. However in many of them, the yield is low according to cultivars used and the environment. This research was carried out in order to evaluate the ability of cultivars to adapt to different environments. The performance of three cultivars from Côte d'lvoire and Burkina Faso: Ivory seed coat (ISC); Beige red seed coat (BRC) and Black seed coat (BSC) were tested. The test was conducted in two locations representing two different agro-climatic conditions and different soil types in Côte d'Ivoire. Eleven agronomic parameters selected from the Bambara groundnut descriptor were measured: two phenological parameters, six growth and three yield parameters. There were study sites $x$ seeds origin interaction for all cultivars. The best values of yield parameters were obtained with seeds from Burkina-faso. Evaluation of field performance showed that when cultivation was carried out in Abidjan (south), the best values of phenological parameters were observed for ISC-CI, ISC-BF and BSC-BF. Cultivar BSC-Cl gave the highest values of growth parameters. The best values of seed harvest index (SHI) and seeds weight per plant (SWP) were obtained with cultivars ISC and BSC from Burkina-Faso. When experimentation was conducted in Manfla (Center), the earliest cultivars were BRC-CI; ISC-CI; ISC-BF and BSC-BF. The best growth parameters were obtained with two cultivars from Côte d'Ivoire (BRC and BSC). The best yield was obtained with cultivar ISC-BF and BSC-BF. 


\section{INTRODUCTION}

In Sub-Saharan Africa, populations are dependent on agriculture. They use agro-biodiversity to produce food mainly for their own needs, care and revenue sources (Tsegaye 1997; Chweya and Eyzaguirre 1999; Howard 2003).But the increase in population and the growing needs to improve the standard of living closely related to quality of life constrains agriculture to undergo changes. These changes were observed with the expanding of cultivation area, replacement of natural vegetation and decrease of number of cultivated species. IPGRI (2002) reported that on 7000 species of plants cultivated 12000 years before Christ, only 150 species were used in global food.A small number of some major plants such as rice, wheat, maize, sorghum, millet, potato and sweet potato are more consumed (Vernooy 2003). The improvement of agriculture and eating habits are one of the hypotheses to explain the disappearing of some species.

In Africa, climate variables (temperature, precipitation) are factors influencing plant growing and production. Agriculture is still traditional and the rainfalls are the main sources of water. Nowadays with climate change, rainfall variation becomes a major problem. The cropping calendars are highly disturbed; inducing a decrease on agricultural products. It is more marked for underutilized crop cultivated for local consumption, such as Bambara groundnut [Vignasubterranea(L.) Verdc.]. It is the third most important grain-legume after groundnut (Arachishypogaea) and cowpea (Vignaungiculata) (Touré et al. 2013). Its cultivation is widespread in most West African countries, particularly in Côte d'Ivoire and Burkina-Faso.

In developing countries, the exploitation of local resources is certainly a way to achieve the objective of food security, particularly for a fast-growing population. However this requires an assessment of the ability of these resources to be well adapted to extremely divergent environments for sustainable agricultural production (Mendelsohn and Dinar 1999). Bambara groundnut (Vignasubterranea (L.) Verdc), an indigenous African legume, plays an important socioeconomic role in the semi-arid regions of Africa. It is a rich source of protein and along with other local sources of protein could help to alleviate nutritional problems in these areas. The crop is grown by subsistence farmers in Africa under traditional low input agricultural systems. It is grown mainly for its edible protein which has high lysine content and therefore has a beneficial complementary effect when consumed with cereals deficient in lysine (Massawe et al. 2005). In Burkina Faso Bambara groundnut is more cultivated in the Northern semi arid zone. In Côte d'Ivoire, it is more cultivated in woodland savannas in the North too. In Côte d'lvoire with a massive population displacement from the north to the south with their eating habits, Bambara groundnut have been introduced in the entire country more yet in center and south. It became important to ensure that these resources can be well adapted in the new environment. Some factors must be considered for increasing productivity and economic profitability. Among them, the choice of cultivars adapted to a particular agro-ecological region is very important. It has been reported by Soares et al. (2014)that in plant breeding programs, the process of selection and recommendation of genotypes is widely used to evaluate the performance of genotypes in different locations. The set of environmental factors react with each other and interact with the plant.

The aim of this study was to evaluate the agronomic performance of Bambara groundnut land races from different origins cultivated in two agroecological areas of Côte d'Ivoire. Three hypothesis were tested:

(1) Agronomic performance of accessions was influenced by the growing area,

(2) Accessions origin have an influence on their ability to adapt to a divergent environment

(3) In the same growing area, yield is similar for all accessions.

\section{MATERIALS AND METHODS}

\section{Plant Material}

Three cultivars of Vignasubterranea from Côte d'Ivoire and Burkina Faso were selected on the germplasm collection maintained at the Nangui Abrogoua University (Abidjan, Côte d'Ivoire). Each cultivar was represented by two accessions. Cultivar was identified using seed coats color (Table 1): Ivory seed coat (ISC); Beige red seed coat (BRC); Black seed coat (BSC). 
Table 1: Cultivar of Vignasubteranea according to the country

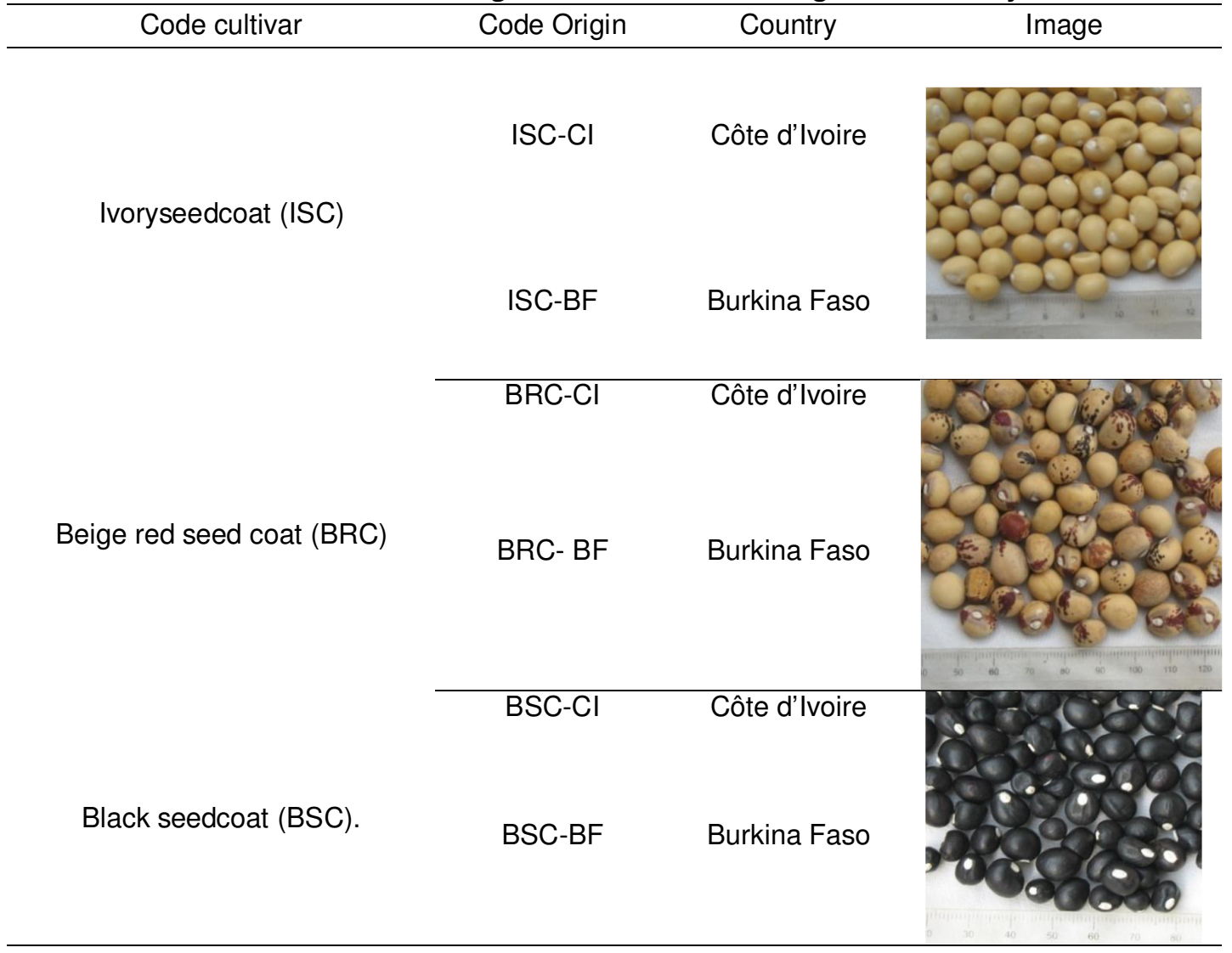

\section{Growing conditions}

Field experiments were conducted at two locations in Côte d'Ivoire, representing different agro-climatic conditions and different soil types.

At Abidjan, in the south, experiments were conducted at Nangui Abrogoua University experimental station located between latitudes $5^{\circ} 17^{\prime} \mathrm{N}$ and $5^{\circ} 31^{\prime} \mathrm{N}$ and longitude $3^{\circ} 45^{\prime} \mathrm{W}$ and $4^{\circ} 31^{\prime} \mathrm{W}$. The climate of the experimental site falls within the semideciduous forest agro-ecological zone with an average annual rainfall $>2,000 \mathrm{~mm}$. The average daily temperature is $28^{\circ} \mathrm{C}$, with annual amplitude of $5-10^{\circ} \mathrm{C}$. The study area is a fallow land mainly covered by Chromolaenaodorata (L.) King \& H.E. Robins (Asteraceae) and Panicum maximum Jacq. (Poaceae). The soil structure is more or less deep, well developed with low proportion of stones ranging from 24 to $37 \%$. This soil is rich in organic matter and very weakly acidic ( $\mathrm{pH} \mathrm{5-7)} \mathrm{in} \mathrm{the} \mathrm{surface} \mathrm{horizons.}$

At Manfla in center, experiment was conducted on farm. Manfla village is located to $400 \mathrm{~km}$ north Abidjan between latitudes $7^{\circ} 20^{\prime} \mathrm{N}$ and $7^{\circ} 25^{\prime} \mathrm{N}$ and longitude $5^{\circ} 50^{\prime} \mathrm{W}$ and $5^{\circ} 55^{\prime} \mathrm{W}$. Annual rainfall varies from 800 to $1400 \mathrm{~mm}$ with a long-term mean of 1200 $\mathrm{mm}$, and the annual mean temperature is $27^{\circ} \mathrm{C}$. The vegetation is a wood land savanna. The study site is a natural fallow plot with vegetation mainly composed of Chromoleanaodorata and Panicummaximum. Soils in the study area were deep, friable and sandy-silt. Analysis at a soildepth of $20 \mathrm{~cm}$ indicated the following characteristics: $\mathrm{pH} 6.45,57 \%$ sand, $36 \%$ silt,7\% clay, $6 \%$ organic matter, $3.5 \mathrm{~g} / \mathrm{kg}$ of total $\mathrm{N}, 24.4 \mathrm{~g} / \mathrm{kg}$ of available $\mathrm{P}$ and $0.45 \mathrm{~g} / \mathrm{kg}$ of $\mathrm{K}$ (Kouassi and Zoro $\mathrm{Bi}$ 2010).

\section{Experimental design and cultural practice}

Experimental design was the same in the two sites. The field lay out was three completely randomized blocks, with one replication per block. Blocks were spaced 1 meter apart and consisted of 6 plots resulting in six mounds of $6 \mathrm{~m} \times 5 \mathrm{~m}$ and $0.30 \mathrm{~m}$ high. A total of 18 plots were carried out per site. On each plot, six rows of five plants corresponding to one plant per $\mathrm{m}^{2}$ (1 plant/ $\mathrm{m}^{2}$ ) were established. Each plot containing 30 accessions. The seeds were sown at $3 \mathrm{~cm}$ depth with a spacing of $1 \mathrm{~m}$. The blocks were weeded weekly with a hoe to prevent the presence of any interaction between planting system, plant spacing and weeds. Disease and pest control was carried out using a carbamate-based insecticide applied when needed.

\section{Parameters measured}

Eleven agronomic parameters selected from the Bambara groundnut descriptor (IITA et al., 2000) were measured: Two phenological parameters, six parameters of growth and three yield parameters. The phenological parameters were: Emergence time of $50 \%$ of plants (EmT); the time to $50 \%$ flowering (FwT). The parameters of growth were: plant height $(\mathrm{PH})$; plant diameter (PD); terminal leaflet length (TLL); terminal leaflet large (TLI), number of branches per plant (BN); number of days from sowing to plant maturity (DPM). The three yield parameters were: 
Seed harvest index (SHI); seeds weight per plant (SWP); number of pods per plants (NPP).

\section{Data analysis}

Mean values and standard deviations were calculated for each of the traits in each accession and cultivars. A fixed-effects model ANOVA was performed to check variations between and within cultivars using SAS statistical Package (SAS 1999). For each parameter, when the null hypothesis related to the ANOVA was rejected, multiple comparisons using the least significant difference (LSD) test were carried out to determine differences between cultivars. All LSD tests were carried out at $\alpha=0.05$ significance level.

\section{RESULT}

Influence of the study site and the origin of the seeds

Comparison of agronomic traits using a multivariate analysis of variance (MANOVA) showed a significant difference between the two sites and between the origins of seeds for all cultivars of Vignasubterranea.

Table 2 gives values of parameters measured according to interactions of study sites and seeds origin for cultivar Ivory seed coat (ISC). Interactions between study sites and seeds origin showed a significant difference for ISC performance. Analysis of table 2indicated that this difference was due to 9 out of 11 parameters measured. No difference was observed for EmT and BN. Flowering was most rapid when seeds were from both countries and experimentation was conducted in Abidjan. But plant maturity was faster for seeds from Burkina-Faso and cultivated in Manfla. For growth parameters, the highest values were obtained with seeds from Côte d'lvoire and cultivated in Abidjan (PH and TLL) or Manfla (TLI). The LSD showed that there is no significant difference between both experiment sites for plant diameter (PD).
For the three yield parameters: seed harvest index (SHI); seed weight per plant (SWP); number of pods per plant (NPP); the best values were obtained with seeds from Burkina-faso and cultivated in Abidjan.

Table 3 documented the ranges of variation according to the interaction between study sites and seeds origin for Beige red seed coat (BRC) and the results of statistical analyses performed to test difference between them. The ANOVA highlighted significant difference for all the 11 traits measured. Two traits (EmT and FwT) differentiated completely the study site and seeds origin, while the nine remaining traits allowed partial distinctions. Germination was faster for seeds from Côte d'Ivoire and cultivated in Manfla. However, flowering was faster on Abidjan site with seeds from Côte d'lvoire. For four parameters, that is, the three yield parameters and number of days from sowing to plant maturity (DPM), the highest values were observed with seeds from Burkina Faso and cultivated at Abidjan. The best values of plant height $(\mathrm{PH})$; terminal leaflet length (TLL) and number of branches per plant (BN) were obtained with seeds from Côte d'Ivoire and cultivated in both sites. Plant diameter was highest with seeds from Côte d'Ivoire and grown in Manfla. Only terminal leaflet large (TLI) gives the best value for Côte d'Ivoire and Burkina Faso in the same site.

Table 4 shows the values of parameters according to interaction between study sites and seeds origin for Black seed coat (BSC). Excepted number of branches per plant (BN), significant difference was observed for all parameters measured in Black seed coat (BSC). Two traits, number of pods per plants (NPP) and the time to $50 \%$ flowering (FwT) differentiated completely the two study sites combined with seeds origin. Germination was faster for seeds from Burkina Faso than Côte d'lvoire. The weak flowering time was obtained with seeds from BurkinaFaso and cultivated in Abidjan. Growth parameters were high with seeds from Côte d'Ivoire. However, the best values of yield parameters were observed with seeds from Burkina-Faso and cultivated in Abidjan.

Table 2: Values of parameters measured according to interaction study sites and seeds origin for cultivar Ivory seed coat (ISC)

\begin{tabular}{|c|c|c|c|c|c|c|}
\hline \multirow[b]{3}{*}{ Parameters } & \multicolumn{4}{|c|}{ Origin and study site } & \multirow{2}{*}{\multicolumn{2}{|c|}{ Statistical test }} \\
\hline & \multicolumn{2}{|c|}{ Côte d'Ivoire } & \multicolumn{2}{|l|}{ Burkina Faso } & & \\
\hline & Abidjan & Manfla & Abidjan & Manfla & $F$ & $P$ \\
\hline EmT (days) & $7.00 \pm 0.00$ & $7.00 \pm 0.00$ & $7.00 \pm 0.00$ & $7.00 \pm 0.00$ & 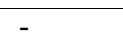 & \\
\hline FwT (days) & $33.00 \pm 0.00^{c}$ & $49.58 \pm 4.62^{\mathrm{a}}$ & $33.00 \pm 0.00^{c}$ & $42.25 \pm 0.44^{b}$ & 516.2 & $<0.001$ \\
\hline DPM (days) & $109.67 \pm 14.55^{\mathrm{a}}$ & $109.00 \pm 0.00^{a}$ & $93.69 \pm 2.36^{b}$ & $91.00 \pm 0.00^{\mathrm{b}}$ & 53.43 & $<0.001$ \\
\hline $\mathrm{PH}(\mathrm{cm})$ & $25.54 \pm 3.52^{\mathrm{a}}$ & $23.39 \pm 3.79^{b}$ & $22.65 \pm 3.32^{\mathrm{b}}$ & $21.91 \pm 2.78^{b}$ & 8.45 & $<0.001$ \\
\hline $\mathrm{PD}(\mathrm{cm})$ & $55.39 \pm 9.88^{a}$ & $57.23 \pm 15.5^{a}$ & $44.03 \pm 9.63^{b}$ & $45.13 \pm 8.98^{b}$ & 14.07 & $<0.001$ \\
\hline TLL (cm) & $7.31 \pm 1.13^{a}$ & $6.63 \pm 0.78^{b}$ & $6.67 \pm 1.06^{\mathrm{b}}$ & $6.58 \pm 0.98^{b}$ & 4.64 & $<0.001$ \\
\hline TLI & $2.17 \pm 0.28^{b c}$ & $2.44 \pm 0.28^{a}$ & $2.07 \pm 0.35^{c}$ & $2.34 \pm 0.82^{\mathrm{ab}}$ & 4.70 & 0.004 \\
\hline BN & $7.46 \pm 1.41^{\mathrm{a}}$ & $7.42 \pm 2.28^{\mathrm{a}}$ & $7.33 \pm 1.45^{\mathrm{a}}$ & $6.79 \pm 1.20^{\mathrm{a}}$ & 1.18 & 0.33 \\
\hline NPP & $96.87 \pm 39.36^{\mathrm{ab}}$ & $26.35 \pm 20.63^{c}$ & $107.78 \pm 61.4^{\mathrm{b}}$ & $81.50 \pm 31.80^{\mathrm{b}}$ & 23.93 & $<0.001$ \\
\hline $\operatorname{SWP}(\mathrm{kg})$ & $28.97 \pm 16.49^{b}$ & $1.98 \pm 1.54^{d}$ & $35.84 \pm 8.08^{a}$ & $7.49 \pm 5.59^{c}$ & 89.19 & $<0.001$ \\
\hline $\mathrm{SHI}$ & $0.45 \pm 0.14^{b}$ & $0.06 \pm 0.05^{d}$ & $0.65 \pm 0.12^{\mathrm{a}}$ & $0.20 \pm 0.13^{c}$ & 180.69 & $<0.001$ \\
\hline
\end{tabular}


Table 3: Values of parameters measured according to interaction study sites and seeds origin for cultivar Beige red seed coat (BRC)

\begin{tabular}{|c|c|c|c|c|c|c|}
\hline \multirow[b]{3}{*}{ Parameters } & \multicolumn{4}{|c|}{ Origin and study site } & \multirow{2}{*}{\multicolumn{2}{|c|}{ Statistical test }} \\
\hline & \multicolumn{2}{|c|}{ Côte d'Ivoire } & \multicolumn{2}{|l|}{ Burkina Faso } & & \\
\hline & Abidjan & Manfla & Abidjan & Manfla & $F$ & $P$ \\
\hline EmT (days) & $7.59 \pm 0.50^{c}$ & $7.00 \pm 0.00^{d}$ & $8.00 \pm 0.00^{b}$ & $8.52 \pm 0.87^{a}$ & 62.11 & $<0.001$ \\
\hline FwT(days) & $38.24 \pm 1.59^{d}$ & $51.15 \pm 1.00^{a}$ & $39.00 \pm 0.00^{c}$ & $52.66 \pm 3.18^{a}$ & 740.43 & $<0.001$ \\
\hline DPM (days) & $125.65 \pm 2.39^{a}$ & $124.54 \pm 13.5^{\mathrm{a}}$ & $115.65 \pm 2.26^{c}$ & $119.38 \pm 0.50^{\mathrm{b}}$ & 34.55 & $<0.001$ \\
\hline $\mathrm{PH}(\mathrm{cm})$ & $30.3 \pm 30.66^{a}$ & $30.56 \pm 3.92^{\mathrm{a}}$ & $27.05 \pm 4.00^{\mathrm{b}}$ & $28.79 \pm 4.67^{a}$ & 34.55 & $<0.001$ \\
\hline PD (cm) & $65.16 \pm 2.39^{a}$ & $71.53 \pm 14.01^{\mathrm{a}}$ & $56.84 \pm 14.09^{b}$ & $64.96 \pm 12.3^{a}$ & 4.80 & $<0.001$ \\
\hline TLL $(\mathrm{cm})$ & $7.83 \pm 1.06^{\mathrm{a}}$ & $7.66 \pm 0.64^{\mathrm{a}}$ & $7.03 \pm 1.22^{\mathrm{b}}$ & $7.29 \pm 0.9^{\mathrm{ab}}$ & 4.88 & $<0.001$ \\
\hline TLI & $2.33 \pm 0.3^{b}$ & $2.66 \pm 0.29^{a}$ & $2.41 \pm 0.41^{\mathrm{b}}$ & $57.38 \pm 39.5^{b}$ & 11.02 & $<0.001$ \\
\hline BN & $6.78 \pm 1.63^{\mathrm{ab}}$ & $7.3 \pm 1.29^{a}$ & $6.44 \pm 1.56^{b}$ & $6.05 \pm 1.120^{\mathrm{b}}$ & 3.76 & $<0.001$ \\
\hline NPP & $55.95 \pm 46.91^{\mathrm{b}}$ & $60.73 \pm 49.26^{b}$ & $132.40 \pm 73.5^{a}$ & $57.38 \pm 39.5^{b}$ & 15.44 & $<0.001$ \\
\hline SWP $(k g)$ & $11.99 \pm 9.69^{b}$ & $5.53 \pm 5.3^{c}$ & $27.65 \pm 19.59^{\mathrm{a}}$ & $5.18 \pm 3.37^{c}$ & 25.1 & $<0.001$ \\
\hline SHI & $0.35 \pm 0.26^{a}$ & $0.07 \pm 0.05^{b}$ & $0.40 \pm 0.15^{\mathrm{a}}$ & $0.08 \pm 0.03^{c}$ & 36.46 & $<0.001$ \\
\hline
\end{tabular}

Table 4: Values of parameters measured according to interaction study sites and seeds origin for cultivar Black seed coat (BSC)

\begin{tabular}{lllllll}
\hline & \multicolumn{2}{l}{ Origin and study site } & \multicolumn{3}{l}{ Statistical test } \\
\cline { 2 - 6 } & Côte d'Ivoire & & Burkina Faso & & \\
\cline { 2 - 6 } Parameters & Abidjan & Manfla & Abidjan & Manfla & $F$ & $P$ \\
\hline EmT (days) & $8.00 \pm 0.00^{\mathrm{a}}$ & $8.10 \pm 1.02^{\mathrm{a}}$ & $7.00 \pm 0.00^{\mathrm{b}}$ & $7.00 \pm 0.00^{\mathrm{b}}$ & 54.89 & $<0.001$ \\
FWT (days) & $36.75 \pm 2.97^{\mathrm{c}}$ & $55.75 \pm 2.22^{\mathrm{a}}$ & $32.57 \pm 0.83^{\mathrm{d}}$ & $44.24 \pm 2.0^{\mathrm{b}}$ & 594.20 & $<0.001$ \\
DPM (days) & $129.50 \pm 9.56^{\mathrm{b}}$ & $137.00 \pm 0.00^{\mathrm{a}}$ & $93.50 \pm 3.20 \mathrm{c}$ & $92.00 \pm 0.00^{\mathrm{c}}$ & 667.26 & $<0.001$ \\
PH (cm) & $32.25 \pm 4.04^{\mathrm{a}}$ & $31.37 \pm 4.45 \mathrm{a}$ & $21.67 \pm 3.33^{\mathrm{b}}$ & $20.56 \pm 2.93^{\mathrm{b}}$ & 81.32 & $<0.001$ \\
PD (cm) & $74.03 \pm 18.53^{\mathrm{a}}$ & $68.72 \pm 15.48^{\mathrm{a}}$ & $43.37 \pm 7.30^{\mathrm{b}}$ & $40.92 \pm 10.83$ & 47.86 & $<0.001$ \\
TLL (cm) & $8.35 \pm 1.14^{\mathrm{a}}$ & $7.66 \pm 0.93^{\mathrm{b}}$ & $6.83 \pm 0.93^{\mathrm{c}}$ & $6.56 \pm 1.00^{\mathrm{c}}$ & 18.52 & $<0.001$ \\
TLI & $3.30 \pm 0.68^{\mathrm{ac}}$ & $2.84 \pm 0.31^{\mathrm{b}}$ & $2.29 \pm 0.90^{\mathrm{c}}$ & $2.23 \pm 0.35^{\mathrm{c}}$ & 18.10 & 0.004 \\
BN & $6.96 \pm 1.73^{\mathrm{a}}$ & $7.45 \pm 1.00^{\mathrm{a}}$ & $7.06 \pm 1.27^{\mathrm{a}}$ & $7.51 \pm 1.56^{\mathrm{a}}$ & 1.06 & 0.33 \\
NPP & $12.71 \pm 9.88^{\mathrm{d}}$ & $35.65 \pm 29.00^{\mathrm{c}}$ & $92.73 \pm 39.42^{\mathrm{a}}$ & $73.51 \pm 31.54^{\mathrm{b}}$ & 38.24 & $<0.001$ \\
SWP(kg) & $1.14 \pm 0.01^{\mathrm{c}}$ & $2.97 \pm 2.07^{\mathrm{c}}$ & $32.26 \pm 13.31^{\mathrm{a}}$ & $9.46 \pm 6.20^{\mathrm{b}}$ & 91.91 & $<0.001$ \\
SHI & $0.02 \pm 0.02^{\mathrm{C}}$ & $0.05 \pm 0.04^{\mathrm{c}}$ & $0.65 \pm 0.09^{\mathrm{a}}$ & $0.30 \pm 0.14^{\mathrm{b}}$ & 24.17 & $<0.001$ \\
\hline
\end{tabular}

\section{Field performance of cultivars}

When cultivation was carried out in Abidjan, comparison of agronomic traits using analysis of variance (ANOVA) showed a significant difference between the three cultivars. As shown in table 5, this difference is based on all the traits measured. The best values of phenological parameters were observed for ISC-CI, ISC-BF and BSC-BF. Emergence of plants and the flowering were most rapid for these cultivars 7 and 33 days after sowing respectively. Cultivar BSC$\mathrm{Cl}$ gave the highest values of growth parameters. However, the highest number of pods per plants was observed with the cultivar Beige red seed coat (BRC) from Burkina-Faso. The best values of seed harvest index $(\mathrm{SHI})$ and seeds weight per plant (SWP) were given by cultivars ISC and BSC from Burkina-Faso.

When experiment was conducted at Manfla, analysis of variance showed a significant difference between cultivars (Table 6). The earliest cultivars were $\mathrm{BRC}-\mathrm{Cl}$; ISC-Cl; ISC-BF and BSC-BF. But flowering and days from sowing to plant maturity was faster with cultivar ISC-BF. The best growth parameters were obtained with two cultivars from Côte d'Ivoire (BRC and BSC). The highest number of pods per plants (NPP) was obtained with cultivar ISC-BF. However, seed harvest index (SHI) and seeds weight per plant (SWP) were better with cultivar BSC-BF. 
Table 5: Comparison of agronomic performance of six accessions of Vignasubterranea cultivated to Abidjan (South of Côte d'Ivoire) and results of

\begin{tabular}{|c|c|c|c|c|c|c|c|c|}
\hline \multicolumn{9}{|c|}{ statistical tests } \\
\hline Parameters & BRC-Cl & BRC-BF & ISC-CI & ISC-BF & BSC-Cl & BSC-BF & $F$ & $P$ \\
\hline EmT (days) & $7.60 \pm 0.50^{b}$ & $8.00 \pm 0.00^{a}$ & $7.00 \pm 0.00^{c}$ & $7.00 \pm 0.00^{c}$ & $8.00 \pm 0.00^{a}$ & $7.00 \pm 0.00^{C}$ & 223.90 & $<0.001$ \\
\hline FwT (days) & $38.00 \pm 1.59^{b}$ & $39.00 \pm 0.00^{a}$ & $33.00 \pm 0.00^{d}$ & $33.00 \pm 0.00^{d}$ & $36.75 \pm 2.97^{c}$ & $32.58 \pm 0.83^{d}$ & 235.50 & $<0.001$ \\
\hline DPM (days) & $125.64 \pm 2.39^{a}$ & $115.80 \pm 2.26^{b}$ & $109.66 \pm 14.60^{c}$ & $93.69 \pm 2.36^{d}$ & $129.50 \pm 9.56^{a}$ & $93.52 \pm 3.20^{d}$ & 144.20 & $<0.001$ \\
\hline $\mathrm{PH}(\mathrm{cm})$ & $30.00 \pm 3.66^{b}$ & $27.52 \pm 4.00^{c}$ & $25.54 \pm 3.52^{d}$ & $22.65 \pm 3.32^{e}$ & $32.25 \pm 4.04^{a}$ & $21.76 \pm 3.33^{e}$ & 42.65 & $<0.001$ \\
\hline $\mathrm{PD}(\mathrm{cm})$ & $65.12 \pm 13.30^{b}$ & $56.84 \pm 14.10^{c}$ & $55.29 \pm 9.88^{c}$ & $44.03 \pm 9.64^{d}$ & $74.03 \pm 18.53^{a}$ & $43.37 \pm 7.31^{d}$ & 30.51 & $<0.001$ \\
\hline TLL(cms) & $7.80 \pm 1.06^{\mathrm{a}}$ & $7.03 \pm 1.22^{\mathrm{bc}}$ & $7.31 \pm 1.13^{b}$ & $6.67 \pm 1.06^{c}$ & $8.35 \pm 1.15^{\mathrm{a}}$ & $6.83 \pm 0.93^{b c}$ & 10.80 & $<0.001$ \\
\hline $\mathrm{TLI}(\mathrm{cm})$ & $2.30 \pm 0.30^{b c}$ & $2.41 \pm 0.40^{b}$ & $2.17 \pm 0.2^{\mathrm{cd}}$ & $2.07 \pm 0.35^{d}$ & $3.3 \pm 0.68^{a}$ & $2.30 \pm 0.90^{\mathrm{bcd}}$ & 21.31 & $<0.001$ \\
\hline BN & $6.80 \pm 1.64^{b c}$ & $6.44 \pm 1.56^{c}$ & $7.47 \pm 1.41^{\mathrm{a}}$ & $7.33 \pm 1.44^{\mathrm{ab}}$ & $6.96 \pm 1.73^{\mathrm{abc}}$ & $7.06 \pm 1.27^{\mathrm{abc}}$ & 2.66 & 0.023 \\
\hline NPP & $56.34 \pm 46.9^{c}$ & $132.40 \pm 73.50^{a}$ & $96.90 \pm 39.40^{b}$ & $107.78 \pm 61.40^{b}$ & $12.71 \pm 9.88^{d}$ & $92.73 \pm 39.18^{b}$ & 20.93 & $<0.001$ \\
\hline SWP (kg) & $12.00 \pm 9.69^{c}$ & $27.65 \pm 19.60^{b}$ & $29.00 \pm 16.50^{b}$ & $35.84 \pm 8.08^{a}$ & $14.1 \pm 1.01^{d}$ & $32.26 \pm 13.31^{\mathrm{ab}}$ & 30.53 & $<0.001$ \\
\hline SHI & $0.40 \pm 0.26^{b c}$ & $0.40 \pm 0.15^{\mathrm{bc}}$ & $0.45 \pm 0.14^{b}$ & $0.65 \pm 0.12^{a}$ & $0.02 \pm 0.02^{c}$ & $0.65 \pm 0.09^{a}$ & 68.02 & $<0.001$ \\
\hline
\end{tabular}

Table 6: Comparison of agronomic performance of six accessions of Vignasubterranea cultivated to Manfla (Center of Côte d'Ivoire)and results of

\begin{tabular}{|c|c|c|c|c|c|c|c|c|}
\hline Parameters & BRC-Cl & BRC-BF & ISC-CI & ISC-BF & BSC-Cl & BSC-BF & $F$ & $P$ \\
\hline EmT (days) & $7.00 \pm 0.00^{c}$ & $8.52 \pm 0.87^{a}$ & $7.00 \pm 0.00^{c}$ & $7.00 \pm 0.00^{c}$ & $8.10 \pm 1.02^{b}$ & $7.00 \pm 0.00^{c}$ & 52.24 & $<0.001$ \\
\hline FwT (days) & $51.00 \pm 1.00^{c}$ & $52.67 \pm 3.18^{b}$ & $49.60 \pm 4.62^{d}$ & $42.25 \pm 0.44^{f}$ & $55.75 \pm 2.22^{a}$ & $44.24 \pm 2.00^{\mathrm{e}}$ & 100.88 & $<0.001$ \\
\hline DPM (days) & $125.00 \pm 13.60^{b}$ & $109.40 \pm 0.50^{c}$ & $109.00 \pm 0.00^{c}$ & $91.00 \pm 0.00^{d}$ & $137.00 \pm 0.00^{a}$ & $92.00 \pm 0.00^{d}$ & 242.09 & $<0.001$ \\
\hline $\mathrm{PH}(\mathrm{cm})$ & $31.00 \pm 3.92^{\mathrm{a}}$ & $28.79 \pm 4.67^{b}$ & $23.40 \pm 3.79^{c}$ & $21.91 \pm 2.78^{\mathrm{cd}}$ & $31.37 \pm 4.45^{\mathrm{a}}$ & $20.56 \pm 2.93^{d}$ & 46.08 & $<0.001$ \\
\hline PD (cm) & $72.00 \pm 14.00^{a}$ & $64.93 \pm 12.30^{a}$ & $57.20 \pm 15.50^{c}$ & $45.13 \pm 8.98^{b}$ & $68.72 \pm 15.48^{a}$ & $40.92 \pm 10.83^{b}$ & 29.33 & $<0.001$ \\
\hline TLL (cm) & $7.70 \pm 0.64^{a}$ & $7.29 \pm 0.87^{a}$ & $6.63 \pm 0.78^{b}$ & $6.58 \pm 0.98^{b}$ & $7.66 \pm 0.93^{a}$ & $6.56 \pm 1.00^{\mathrm{b}}$ & 10.73 & $<0.001$ \\
\hline $\operatorname{TLI}(\mathrm{cm})$ & $2.78 \pm 0.29^{a}$ & $2.70 \pm 0.37^{b}$ & $2.44 \pm 0.28^{b}$ & $2.34 \pm 0.82^{b}$ & $2.84 \pm 0.32^{a}$ & $2.23 \pm 0.34^{b}$ & 8.37 & $<0.001$ \\
\hline $\mathrm{BN}$ & $7.30 \pm 1.29^{a}$ & $6.05 \pm 1.12^{b}$ & $7.42 \pm 2.28^{a}$ & $6.79 \pm 1.20^{a b}$ & $7.45 \pm 1.00^{\mathrm{a}}$ & $7.51 \pm 1.56^{a}$ & 3.38 & 0.023 \\
\hline NPP & $61.00 \pm 49.30^{b}$ & $57.38 \pm 59.50^{b}$ & $26.40 \pm 20.60^{d}$ & $81.50 \pm 31.80^{a}$ & $35.65 \pm 29 \mathrm{~cd}$ & $73.51 \pm 31.55^{\mathrm{ab}}$ & 8.95 & $<0.001$ \\
\hline SWP (kg) & $5.50 \pm 5.31^{b c}$ & $5.18 \pm 5.38^{\mathrm{bc}}$ & $1.97 \pm 1.54^{d}$ & $7.49 \pm 5.59^{b}$ & $2.97 \pm 2.07^{d}$ & $9.46 \pm 6.20^{\mathrm{a}}$ & 10.19 & $<0.001$ \\
\hline $\mathrm{SHI}$ & $0.10 \pm 0.06^{c}$ & $0.08 \pm 0.06^{c}$ & $0.06 \pm 0.05^{c}$ & $0.20 \pm 0.13^{b}$ & $0.05 \pm 0.04^{c}$ & $0.30 \pm 0.13^{a}$ & 36.91 & $<0.001$ \\
\hline
\end{tabular}




\section{DISCUSSION}

The introduction of new cultivated varieties is a technology aimed at enhancing productivity and quality of plants taking into account the environmental stress. Our study showed significant origin $\mathrm{x}$ experimentation site interaction in major traits among the three cultivars of Vignasubterranea.

For the phenological parameters, study showed that accessions from Côte d'lvoire cultivated at the center (Manfla) germinate faster and about 7 days after sown. The germination mean time of the seeds is similar to results of Bonny et Djè (2011). But whatever the origin of accessions, those grown in Abidjan display a short flowering time. Differences in flowering of the cultivars could be attributed to genetic variability or the environmental effects. These observations have been reported by Berchie et al. (2010). Differences in maturity periods have been also observed. Accessions from Burkina Faso reach maturity faster than those from Côte d'lvoire. This result could be indicated that cultivars from Burkina Faso could well adapt to the environmental conditions of Côte d'Ivoire. Number of days from sowing to plant maturity was similar to those reported by Touré et al. (2013).

The general findings of this study are that plants produced with accessions from Côte d'Ivoire and cultivated in Abidjan are more vigorous. Our data corroborate results of Touré et al. (2013) conducted on some accessions of Vignasubterranea from Côte d'Ivoire and those reported by Ouedraogo et al. (2008) on accessions from Burkina Faso. This implies that different environments have different influences on the growth parameters. These results could be explained by the fact that cultivars from Côte d'lvoire were already well adapted to this environment.

For the three cultivars, the yield was better when the accessions were from Burkina-Faso and the culture took place in Abidjan. Indeed, in Abidjan plants produced the highest number of pod and seed weights per plant. Seed harvest index (SHI) was higher in Abidjan too. Two main factors could explain these results, rainfall and pest pressure. In fact, mean rainfall is higher in Abidjan (1704.80 $\mathrm{mm}$ ) than Manfla $(1443.50 \mathrm{~mm})$. The positive effect of water on the productivity per plant in Bambara groundnut has been reported by Cornelissen (2005). Similarly, positive correlation between precipitation and plant productivity have been reported on chickpea (Ciceraeritinum L.) (Jalota et al. 2006), common bean (Phaseoluslunatus L.) (Tefera 2006), cowpea (Vignaunguiculata L.) (Souza et al. 2004), and soybean (Glycine max (L.) Merr.), (Muchowa and Sinclair 1986).The second hypothesis proposed to explain the increase in productivity per plant in Abidjan than Manfla is pest pressure. Abidjan is not the regular production area of V. subterranea. Specific pests are less abundant on the contrary to Manfla where this plant is regularly cultivated with a persistence of pests. This result could be related to the composition of the soil at the study sites. Indeed, Manfla with $57 \%$ sand, soils are so friable that the burial of seeds is not easy.

In a general way, cultivars from Burkina-Faso out-perform those from Côte d'Ivoire. The differences observed could be explained by life cycle of cultivars from both countries. Indeed, cultivars from BurkinaFaso are characterized by a short life cycle. Ludlow and Muchow (1990) indicated that plants having a short cycle reach maturity faster. Plants with short cycles are often characterized by high plasticity development (Loss et al. 1997; Thomson et al. 1997; Cleland et al. 2007). The plasticity of V. subterranea in response to photoperiod and temperature have been reported by several authors (Linnemann et al. 1995; Brink et al. 2000). The short life cycle allowed cultivars from Burkina Faso to complete their production cycle before the onset of drought.

The mean yield of accessions tested vary between $141 \mathrm{~kg} / \mathrm{ha}$ and $3220 \mathrm{~kg} / \mathrm{ha}$ in Abidjan and $197 \mathrm{~kg} / \mathrm{ha}$ to $946 \mathrm{~kg} / \mathrm{ha}$ in Manfla. These values were higher than those reported by Ouédraogo et al. (2008) for V. subterranea cultivated in Burkina Faso with $225.7 \mathrm{~kg} / \mathrm{ha}$ à $944 \mathrm{~kg} / \mathrm{ha}$. Differences between our study and Ouédraogo et al. (2008) study could be attributed to the different genotype and climatic conditions of each country. We noted that accessions having a long life cycle were less productive. Impact of climate change on agronomic performance of plant has been also reported by some authors (Seguin 2003; Souza et al. 2004).

\section{CONCLUSION}

The variation of productivity of plants in a particular yield is attributed to climate variation. This study was conducted to evaluate the agronomic performance of six accessions of voandzou [Vignasubterranea (L.) Verdc.], which consisted of three cultivars from Burkina Faso and Côte d'Ivoire cultivated in contrasted agroecological zones. Based on the findings of this study, it can be concluded that the yield of $\mathrm{V}$. subterranean is better in the south (Abidjan) than the center (Manfla). The best values of yield parameters were obtained with seeds from Burkina Faso and cultivated Abidjan. The best yield was obtained with cultivar ISC-BF and BSC-BF. So these cultivars could be used to intensify production of $V$. subterranea in Côte d'Ivoire.

\section{ACKNOWLEDGEMENT}

The helpful comments of Pr NIEMENAK Nicolas of Yaoundé I University (Cameroon) and the anonymous reviewers resulted in the significant improvement of the manuscript.

\section{REFERENCE}


Berchie JN, Sarkodie-Addo J, Adu-Dapaah H, Agyemang A, Addy S, Asare E and Donkor $J$ (2010). Yield evaluation of the tree early maturing Bambara goundnut (Vignasubterranea L. Verdc landraces at the SCIR-Crops Reaserchlntitute, FumesuaKumasi, Ghana. J. Agron. 9: 175-179.

Bonny SB and Djè $Y$ (2011).Variabilitémorphologiqueetagronomiq ue des variétéstraditionnelles de voandzou [Vignasubterranea (I.) verdc. (fabaceae)] de Cote d'Ivoire. J. appl. biosci.41: 2820 - 2835.

Brink M, Sibuga KP, Tarimo AJP and Ramolemana GM (2000). Quantifying photothermal influences on reproductive development in Bambara groundnut (Vignasubterranea): modeles and their validation. . Field Crops Res. 66 (1): 1-14.

Chweya JA and Eyzaguirre PB (1999). The biodiversity of traditional leavy vegetables. Rome, IPGRI, 182 pages.

Cleland EE, Chuine I, Menzel A, Mooney HA and Schwartz MD (2007).Shifting plant phenology in response to global change.Trends Ecol. Evol. 22 (7): 357-365.

Cornelissen RLEJ (2005). Modelling variation in the physiology of Bambara Groundnut (Vignasubterranea (L.)Verdc. ). Cranfield (UK):,Cranfield University at Silsoe; PhD: 190 Pages.

Howard PL(2003). Women and plants: gender relations in biodiversity management and conservation. Publish (London). 320 Pages

IPGRI (2002). Neglected and underutilized plant species: strategic action plan of the International Plant Genetic Resources Institute (IPGRI). Rome: IPGRI, 30 pages.

Jalota SK, Sood A and Harmanc WL (2006).Assessing the response of chickpea (Ciceraeritinum L.) yield to irrigation water on two soils in Punjab (India): a simulation analysis using the CROPMAN model.Agric.Water.Manag. 79 (3): 312-320.

Kouassi NJ and Zoro Bi IA (2010). Effect of sowing density and technique on yield and yield components in Bambara groundnut (Vignasubterranea) in woodland savannahs of Côte d'Ivoire. Exp. Agric. 46 (1): 99-110.

Linnemann AR, Westphal E and Wessel M (1995). Photoperiod regulation of development and growth in Bambara groundnut (Vignasubterranea). Field Crop Res. 40 (5): 39-47.

Loss SP, Siddique KHM and Martin LD (1997). Adaptation of faba bean (Viciafaba L.) to dryand Mediterranean-type environments II. Phenology, canopy development, radiation absorbtion and biomass partitioning. Field Crop Res. 52 (1-2): 29-41.
Ludlow MM and Muchow RC (1990).A critical evaluation of traits for improving crop yield in water-limited environments.Agronomy 43: 107-153.

Massawe FJ, Mwale SA, Azam-Ali SN and Roberts JA (2005).Breeding in Bambara groundnut (Vignasubterranea (L.) Verdc.): strategic considerations. Afr. J. Biotechnol.4 (6): 463471.

Mendelsohn R and Dinar A (1999). Climate change, agriculture, and developing countries: does adaptation matter? World Bank Res. Obs. 14 (2): 277-293.

Muchowa RC and Sinclair TR (1986). Water and nitrogen limitations in soybean grain production II. Field and model analyses. Field Crop Res. 15 (2): 143-156.

Ouedraogo M, Ouedraogo JT, Tignéré J-B, Balma D, Dabiré CB and Konaté B (2008). Characterization and evaluation of accessions of Bambara groundnut (Vignasubterranea (L.)Verdcourt) from Burkina Faso.Sci. Nat. 5 (2): 191 - 197.

SAS (1999).SAS/ETS User's Guide; version 6. Cary, North Carrolina (USA), SAS Institute.

Seguin B (2003).Adaptation des systèmes de production agricole au changementclimatique.Compterendu Geosciences 335: 569-575

Soares ER, Fernandes R, da Silva Londero L, Dos Santos DL, Corrêa SCS, Corrêa EAS, dos Santos RC, Gomes AP, Galon L, Fabiana FP and GonçalvesRdS (2014). Agronomic Performance of Cultivars of Upland Rice in the Southern of the Region of Rondônia, Brazil.Agri. Sci. 5: 513-518.

Souza RP, Machado EC, Silva JAB, Lagôa AMMA and Silveira JAG (2004). Photosynthetic gas exchange, chlorophyll fluorescence and some associated metabolic changes in cowpea (Vignaunguiculata) during water stress and recovery. Environ. Exp. Bot. 51 (1): 45-56.

Tefera T (2006). Yield of common bean cultivars under semi-arid conditions in eastern Ethiopia. . Trop. Sci. 46 (3): 155-159.

Thomson BD, Siddique KHM, Barr MD and Wilson JM (1997)). Grain legume species in low rainfall mediterranean-type environments I. Phenology and seed yield. Field Crop Res 54 (2-3): 173-187.

Touré Y, Koné M, Silué S and Kouadio YJ (2013). Prospection, collecteetcaracterisationagromorphologique des morphotypes de voandzou [Vigna subterranea (I.) verdc. (fabaceae)] de la zone savanicole en Côte d'Ivoire. Eur Scientific J. 9: 308-325.

Tsegaye B (1997). The significance of biodiversity for sustaining agricultural production and role of women in the traditional sector: the Ethiopian experience. .AgricEcosyst Environ 62 (2-3): 215-227. 
Vernooy $R(2003)$. Les Semences du monde :l'amélioration participative des plantes.

Ottawa (Canada). Publish 120 Pages.

Cite this Article: Komenan-Ani AS, Koffi KK, Kouakou KL, Kouassi KI and Zoro BIA (2016). Agronomic Performance of Cultivars of Vignasubterranea (L.) from Côte d'Ivoire and Burkina Faso Cultivated under different Environments. Greener Journal of Agricultural Sciences, 6(6): 186-194, http://doi.org/10.15580/GJAS.2016.6.042916081. 